\title{
Effect of Turmeric (Curcuma longa) Black Pepper (Piper nigrum) and Azolla Pinnata on
} Waste Water Nile tilapia Fish

Mohamed F. Dowidar ${ }^{1}$, Mohamed A. Abd El-Megid ${ }^{2}$ and Suzan O.M. EL-Werwary ${ }^{2 *}$

${ }^{1}$ Biochemistry Department, Faculty of Veterinary Medicine, Zagazig University, 44511, Egypt

${ }^{2}$ Central Laboratory for Aquaculture Research, Abbassa, Abo Hammad, Sharkia, Egypt

\begin{abstract}
The objective of this study was to investigate the effect of Turmeric (Curcuma longa) with Black Pepper (Piper nigrum) and Azolla Pinnata on Nile tilapia fish weight and the gene expression of growth hormone receptor (GHR) and insulin as growth factor (IGF) of Nile tilapia collected from waste water. A total of 250 Nile tilapia fish divided into 5 groups each of 50 . The first group of apparently healthy fish collected from Central Laboratory for Aquaculture Research El-Abbassa (clean water). The second group collected from waste water of Bahr El-Baqar zone. The third group collected from waste water of Bahr El-Baqar zone and fed on $0.5 \%(5 \mathrm{~g} / \mathrm{kg}$ diet $)$ of each Turmeric (Curcuma longa) and Piper nigrum for 45 days. The fourth group collected from waste water of Bahr El-Baqar zone in the presence of small amount of Azolla Pinnata (Aquatic fern) for 45 days (Azolla grows quickly without feeding on Turmeric and Piper nigrum), while the fifth group collected from waste water of Bahr El-Baqar zone and fed on Turmeric (Curcuma longa) and Piper nigrum for 45 days in presence of Azolla Pinnata. The results cleared that the weight of fish in the first group showed an increase after 45 days but a slight decrease in weight were noticed in the second group in the first 15 days. There was an increase in fish weights in third and fourth groups and a marked increase in the fifth group after 45 days. Moreover, an increase in both GHR and IGF in groups fed on Turmeric and Piper nigrum for 45 days as well as in the presence of Azolla Pinnata.
\end{abstract}

Keywords: Turmeric, Curcuma longa, Piper nigrum, Azolla, Waste Water, Nile tilapia.

\section{Introduction}

Heavy metals in waste water have an effect on fish health by accumulation in their organs especially gills and liver by a quantity more than muscles [1]. Bioaccumulation of heavy metals in fish may critically affects physiological and biochemical status and the growth rate of fish [1]. The aquatic environment and water quality are the main factors that control the state of health and disease in both cultured and wild fish [2]. Bahr El-Baqer is considered as one of polluted regions because its drains contain both industrial and domestic waste water that have an effect on Lake Manzala [3]. It was important to use plants in therapy "back to nature" to avoid using of synthetic drugs that have dangerous side effects [4]. Curcumin is considered as the active ingredient from the spice turmeric that has a potent antioxidant effect [5]. It has hepato protective properties and also it is strongly alleged that turmeric has ability to improve nutrient and digestion metabolism [6].

Black pepper has immunomodulatory roles and they can be used as natural agents that can promote the maintenance of a healthy immune system as it plays a role in growth enhancement [7]. Moreover, Curcumin's absorption was enhanced when black pepper is combined with it, whereas black pepper can enhance the blood concentration of fish that extended the absorption and bioavailability of curcumin so it is recommended that adding black pepper to curcumin [8]. Azolla can grow quickly and they can act as symbiont due to presence of Anbaena group [9]. It also acts as a biofilter to purify water and can remove phosphorus and nitrogen. In addition, it can remove sulfa drugs [10] as well as it removes metals such as $\mathrm{Cd}, \mathrm{Cr}, \mathrm{Pb}, \mathrm{Au}, \mathrm{Sr}, \mathrm{Cu}$ and $\mathrm{Zn}$ [11]. This study aimed to investigate the effect of both Turmeric (Curcuma longa) with Black Pepper (Piper nigrum) and Azolla Pinnata on Nile tilapia that was treated in waste water to avid the dangerous resulted from waste water.

\section{Materials and Methods}

\section{Fish}

Fifty Nile tilapia were obtained from the Central Laboratory for Aquaculture Research El-Abbassa, Abo Hammad, Sharkia. These fish were analyzed and had permissible limits of copper and zinc in muscles $(6.48 \pm 0.03$ and

*Corresponding author e-mail: (suzanelwerwary@yahoo.com), Central Laboratory for Aquaculture 386 Research, Abbassa, Abo Hammad, Sharkia, Egypt. 
$44.12 \pm 0.05 \mathrm{mg} / \mathrm{g}$, respectively) and gills $(9.41 \pm 0.098$ and $81.64 \pm 0.056 \mathrm{mg} / \mathrm{g}$, respectively). There wasn't cadmium in muscles but it was in gills $(9.41 \pm 0.098 \mathrm{mg} / \mathrm{g})$, while iron in muscles and gills were $82.61 \pm 0.029$ and $214.74 \pm 0.042 \mathrm{mg} / \mathrm{g}$ ), so they were used in the current study as a negative control (Group 1). Two hundred Nile Tilapia were obtained from Bahr El-baqar zone, Alhusiniuh, Sharkia. These fishes were analyzed and had limits of copper in muscles and gills $(7.46 \pm 0.23$ and $11.32 \pm 0.03 \mathrm{mg} / \mathrm{g}$, respectively), while, zinc and cadmium in muscle was $66.72 \pm 0.08$ and $0.02 \pm 0.003$ $\mathrm{mg} / \mathrm{g}$, respectively) and in gills was $90.17 \pm 0.05$ and $11.32 \pm 0.03 \mathrm{mg} / \mathrm{g}$, respectively). Iron in muscles and gills was $145.45 \pm 0.007$ and $310.46 \pm 0.05 \mathrm{mg} / \mathrm{g}$, respectively and they were used in current study as positive control (Group 2). All fish were maintained in concrete tanks and their average body weight was $70 \pm 10 \mathrm{~g}$.

\section{Experimental design}

Nile tilapia were collected from Central Laboratory for Aquaculture Research ElAbbassa (fresh water with salinity less than $0.05 \%$, dissolved oxygen $5.1 \pm 0.6 \mathrm{mg} \mid \mathrm{L}, \mathrm{PH}$ 7.5 , total alkalinity $442.99 \pm 11.9$, total ammonia $0.55 \pm 0.07 \mathrm{mg} \mid \mathrm{L}$, unionized ammonia $0.07 \pm 0.001 \mathrm{mg} \mid \mathrm{L}$, Nitrite $0.09 \pm$ $0.0002 \mathrm{mg} \mid \mathrm{L}$, nitrate $0.35 \pm 0.005 \mathrm{mglL}$ and $26^{\circ} \mathrm{C}$ ) they were fed on ingredients of feeding diet without additives. These fishes were used as a negative control group (Group 1).

The 200 Nile tilapies from Baher El Baker (with salinity more than $0.05 \%$, dissolved oxygen $2.12 \pm 0.5 \mathrm{mg} \mid \mathrm{L}, \mathrm{PH} 7.3$, total alkalinity 453.35 -8.7, Total ammonia $39.40 \pm 1.9 \mathrm{mg} \mid \mathrm{L}$, Unionized ammonia $7.02 \pm 1.2 \mathrm{mg} \mid \mathrm{L}$, Nitrite $0.04 \pm 0.08 \mathrm{mg} \mid \mathrm{L}$, nitrate $0.25 \pm 0.55 \mathrm{mg} \mid \mathrm{L}$ and $26^{\circ} \mathrm{C}$ ) were divided into four groups. The first was kept as the same as positive control (Group 2). Group 3: Nile tilapia from Baher El Baker that were fed on ingredients of feeding diet with addition of Turmeric powder $0.5 \%$ (5g/kg diet) [12-14] and $0.5 \%$ Piper nigrum [15] (Table1). Group 4: Nile tilapia from Baher El Baker were exposed to Azolla Pinnata (Aquatic fern) with small amount as Azolla grows quickly [7], and were fed on ingredients of feeding diet without additives (Table 1). Group 5: Nile tilapia from Baher El Baker were exposed to Azolla Pinnata (Aquatic fern) and fed on ingredients of feeding diet with addition of turmeric powder and piper nigrum (Tables 1,2).

All groups were observed along 45 days and were maintained in concrete aquariums with a capacity of 10597.5 Liters, but fish were cultivated in 8831.25 Liters. Nile tilapias were fed twice daily with 5\% from total weight of fish for every aquarium. Fish were individually weighed to the nearest $70 \pm 10$ gram at the beginning of the experiment using a digital balance (Model Ainsworth A-600) and also every 15 days throughout the experimental period [16]. Liver samples were collected from Nile tilapia fish and used immediately for determination of GHR and IGF gene expression using RNeasy Mini Kit (QIAGEN, USA).

Table (1): Ingredients of feeding diet for Nile Tilapia [15,34].

\begin{tabular}{lcc}
\hline \multirow{2}{*}{ Ingredients } & \multicolumn{2}{c}{ Level of ingredients } \\
\cline { 2 - 3 } Fish meal & Traditional diet & Additional diet \\
Soybean meal (SBM) & $10.4 \%$ & $10.4 \%$ \\
Ground corn (CNM) & $42.98 \%$ & $42.98 \%$ \\
Wheat bran (WB) & $20.32 \%$ & $20.32 \%$ \\
Cod fish oil & $15.49 \%$ & $15.49 \%$ \\
Corn oil & $2.31 \%$ & $2.31 \%$ \\
Vitamins Premix & $1.50 \%$ & $1.50 \%$ \\
Minerals Premix & $1.0 \%$ & $1.0 \%$ \\
Starch & $2.0 \%$ & $2.0 \%$ \\
Turmeric powder & $4.0 \%$ & $4.0 \%$ \\
Piper nigrum & - & $0.5 \%$ \\
\hline
\end{tabular}


Table 2: Experimental design of different treatments of waste water fish.

\begin{tabular}{llll}
\hline \multirow{2}{*}{ Groups } & Water & Treatments & \\
\cline { 3 - 3 } & Fresh & Diet treatment & Water treatment \\
\hline $\mathbf{G}_{\mathbf{1}}$ & Waste & Traditional diet & \\
$\mathbf{G}_{\mathbf{2}}$ & Waste & Traditional diet & - \\
$\mathbf{G}_{\mathbf{3}}$ & Waste & Additional diet & - \\
$\mathbf{G}_{\mathbf{4}}$ & Waste & Traditional diet & Exposure to azolla \\
$\mathbf{G}_{\mathbf{5}}$ & Additional diet & Exposure to azolla \\
\hline
\end{tabular}

$\mathrm{G}_{1}$ : (negative control group): fish from Central Laboratory for Aquaculture Research EL-Abbassa (clean water); $\mathrm{G}_{2}$ : (positive control group) fish that were cultivated in waste water; $\mathrm{G}_{3}$ : fish from waste water that were treated with Turmeric (Curcuma longa) with black pepper (Piper nigrum); $\mathrm{G}_{4}$ : fish from waste water that were exposure to Azolla and $\mathrm{G}_{5}$ : fish from waste water that were treated with both Turmeric (Curcuma longa) with black pepper (Piper nigrum) and Azolla.

\section{Gene expression analysis using Quantitative Real Time PCR}

Growth Hormone Receptor (GHR): (5'-CAG ACT TCT ACG CTC AGG TC-3'), (5'-CTG GAT TCT GAG TTG CTG TC-3'). Amplicon (80 bp): Gene Bank (ID): AY973232.1 and Insulin as growth factor (IGF): (5'GTTTGTCTGTGGAGAGCGAGG-3'), (5'GAAGCAGCACTCGTCCACG -3'). Amplicon (bp): 97 and Gene Bank (ID): Y10830.1

\section{Quantitative Real Time PCR (qRT-PCR)}

Triplicate PCR reactions were done for each analyzed sample. Each PCR reaction consisted of, $2.5 \mu \mathrm{L}$ of $1 \mu \mathrm{g} / \mu \mathrm{L}$ cDNA, $12.5 \mu \mathrm{L}$ SYBR Green PCR Master Mix, $0.3 \mathrm{M}$ of both forward and reverse primer and double distilled water to a final volume of $25 \mu \mathrm{L}$. Reactions were analyzed on an Applied Biosystem 7500 Real time PCR detection system under the following conditions: $95^{\circ} \mathrm{C}$ for $10 \mathrm{~min}$ and 45 cycles of $95^{\circ} \mathrm{C}$ for $20 \mathrm{~s}$ then $60^{\circ} \mathrm{C}$ for $20 \mathrm{~s}$ and $72^{\circ} \mathrm{C}$ for $20 \mathrm{~s}$. The fluorescence monitoring takes place at the end of each cycle. 18s rRNA gene can used as reference gene for qPCR data normalization [17].

\section{Statistical analysis}

All experimentally induced changes in IGF and GHR expression were presented as n-fold changes relative compared to controls set as 1 $(100 \%)$. The comparative threshold cycle $(\Delta \Delta \mathrm{CT})$ method [18] was used to calculate relative gene expression ratios [19]. Prior to analysis, qPCR assays were validated by plotting CT values against the logarithms of the dilution factors. Relative gene expression ratios $(\mathrm{R})$ between treated and control groups were calculated using the formula: $\mathrm{R}=2-\Delta \Delta \mathrm{CT}$ with $\Delta \mathrm{CT}=\mathrm{CT}$ (target gene) $-\mathrm{CT}$ (reference gene), with $\Delta \Delta \mathrm{CT}=\Delta \mathrm{CT}$ (treated group) $\Delta \mathrm{CT}$ (untreated control). All data are presented as means \pm standard error (SE) and were analyzed using one way ANOVA, followed by multiple range tests was used to compare differences among individual means [20], with statistical software SAS ANOVA procedure (Statistical Analysis System, 1993). A probability of 0.05 was utilized to account for the statistical difference among means.

\section{Results}

The trials of water and diet treatments of fish to avoid the bad impact of cultivation of fish in waste water revealed the following results. The initial weight was the same for all five groups (73.37 \pm 0.87$)$. The follow up fish weight changes in five groups showed that fish weight after 15 days from the experiment was $88.73 \pm 1.2, \quad 72.04 \pm 0.86, \quad 72.94 \pm 0.86$, $72.84 \pm 0.87$ and $73.00 \pm 0.88$ for the five groups respectively. Nile tilapia fish weight at the end of the experiment was $126.13 \pm 1.44$, $79.07 \pm 0.90, \quad 109.64 \pm 0.51, \quad 102.0 \pm 0.89$ and $116.84 \pm 0.37$ (Table 3). It was noticed an improvement in groups that were treated with turmeric, black pepper and azolla as compared with the group 2 . 
Table 3: Fish weight in different groups at different periods.

\begin{tabular}{lccc}
\hline Treatment & Initial weight of fish & Weight of fish after 15 days & Weight of fish after 45 days \\
\hline $\mathbf{G}_{\mathbf{1}}(\mathrm{g})$ & $73.096 \pm 1.23$ & $88.728 \pm 1.20^{\mathrm{a}}$ & $126.13 \pm 1.44^{\mathrm{a}}$ \\
$\mathbf{G}_{\mathbf{2}}(\mathrm{g})$ & $73.374 \pm 0.87$ & $72.042 \pm 0.856^{\mathrm{b}}$ & $79.07 \pm 0.90^{\mathrm{e}}$ \\
$\mathbf{G}_{\mathbf{3}}(\mathrm{g})$ & $73.374 \pm 0.87$ & $72.941 \pm 0.855^{\mathrm{b}}$ & $109.64 \pm 0.51^{\mathrm{c}}$ \\
$\mathbf{G}_{\mathbf{4}}(\mathrm{g})$ & $73.374 \pm 0.87$ & $72.844 \pm 0.867^{\mathrm{b}}$ & $102.0 \pm 0.89^{\mathrm{d}}$ \\
$\mathbf{G}_{\mathbf{5}}(\mathrm{g})$ & $73.374 \pm 0.87$ & $73.002 \pm 0.877^{\mathrm{b}}$ & $116.48 \pm 0.37^{\mathrm{b}}$ \\
\hline
\end{tabular}

$\mathrm{G}_{1}$ : (negative control group): fish from Central Laboratory for Aquaculture Research EL-Abbassa (clean water); $\mathrm{G}_{2}$ : (positive control group) fish that were cultivated in waste water; $\mathrm{G}_{3}$ : fish from waste water that were treated with Turmeric (Curcuma longa) with black pepper (Piper nigrum); $\mathrm{G}_{4}$ : fish from waste water that were exposure to Azolla and $\mathrm{G}_{5}$ : fish from waste water that were treated with both Turmeric (Curcuma longa) with black pepper (Piper nigrum) and Azolla. Means carrying different superscripts (letters) within the same column were significantly differences at $(\mathrm{P}<0.05)$.

The liver tissue showed a highly significant increase in the level of gene expression activity of growth hormone receptor gene of group 3 that was treated with turmeric and black pepper also group 4 that was treated with Azolla and group 5 that was treated with both turmeric, black pepper and Azolla as compared with both positive and negative control groups (Table 4). The detection of level of gene expression activity of insulin as growth factor in liver tissue showed significant increase in group 3 that was treated with turmeric and black pepper also in group 4 that was treated with Azolla as well as in group 5 that was treated with both turmeric, black pepper and Azolla as compared with both positive and negative control groups (Table 5).

Table 4: Analysis of PCR product of Growth hormone receptor gene in liver tissue of Nile tilapia (Oreochromis niloticus)

\begin{tabular}{lc}
\hline Group & Fold Change Mean \pm Standard Error $)$ \\
\hline G1 & $1.06606 \pm 0.149186$ \\
G2 & $0.547623 \pm 0.19069$ \\
G3 & $2.45439 \pm 0.237686$ \\
G4 & $0.777176 \pm 0.498806$ \\
G5 & $3.696522 \pm 0.437488$ \\
\hline
\end{tabular}

$\mathrm{G}_{1}$ : (negative control group): fish from Central Laboratory for Aquaculture Research EL-Abbassa (clean water); $\mathrm{G}_{2}$ : (positive control group) fish that were cultivated in waste water; $\mathrm{G}_{3}$ : fish from waste water that were treated with Turmeric (Curcuma longa) with black pepper (Piper nigrum); $\mathrm{G}_{4}$ : fish from waste water that were exposure to Azolla and $\mathrm{G}_{5}$ : fish from waste water that were treated with both Turmeric (Curcuma longa) with black pepper (Piper nigrum) and Azolla.

\section{Discussion}

Turmeric supplementation has the ability to increase the growth rate due to improve feed utilization and feed consumption, which are considered as an indicator of increasing nutrient digestibility of turmeric [21]. Moreover, Turmeric can stimulate protein synthesis through enzymatic system [22]. As well as piper nigrum has an ability to control the resistant bacteria which are becoming a threat to human health [23] and can be used as natural agents that promote the maintenance of a healthy immune system and therefore, improve fish weight [7]. Azolla is rich in protein $(25-30 \%)$ [24] and has the ability to improve fish weight. There was significant increase in weight of fish that treated with Curcuma longa and Piper nigrum or azolla and that were treated by turmeric powder, black 
pepper and azolla (Group 5). While, a decrease in weight of fish collected from waste water due to the impact of heavy metals on fish weight.

Table 5: Analysis of PCR product of Insulin gene in liver tissue of Nile tilapia (Oreochromis niloticus)

Group

G1

G2

G3

G4

G5
Fold Change Mean \pm Standard Error)

\author{
$1.1404 \pm 0.270337$ \\ $0.527377 \pm 0.324043$ \\ $0.67543 \pm 0.0903657$ \\ $0.571434 \pm 0.5594856$
}

$0.687961 \pm 0.04285$

$\mathrm{G}_{1}$ : (negative control group): fish from Central Laboratory for Aquaculture Research EL-Abbassa (clean water); $\mathrm{G}_{2}$ : (positive control group) fish that were cultivated in waste water; $\mathrm{G}_{3}$ : fish from waste water that were treated with Turmeric (Curcuma longa) with black pepper (Piper nigrum); $\mathrm{G}_{4}$ : fish from waste water that were exposure to Azolla and $\mathrm{G}_{5}$ : fish from waste water that were treated with both Turmeric (Curcuma longa) with black pepper (Piper nigrum) and Azolla.

The growth in fish is depended on growth hormone that was secreted from the pituitary gland and regulates the somatic growth in addition to organ and tissue growth [25]. These biological functions are depended on insulin like growth factor that released from the liver in response to circulating growth hormone [26]. Analysis of PCR in liver tissues of Nile tilapia showed an increase in the activity of gene expression of both growth hormone receptor (GHR) gene and insulin like growth factor gene (IGF) in Nile tilapia (Oreochromis niloticus) fish that were treated by turmeric powder, black pepper or azolla and that treated with both turmeric powder and black pepper and azolla. Curcumin is considered as a prebiotic that can improve the balance of positive and negative intestinal flora [27] and it can increase the intestinal digestion and absorption that leads to stimulate the growth and improve the general health of fish [25]. The current results are in agreement with Midhun et al. [28] who reported an increase in GH, GHR and IGF when curcumin has been used as feed additive to tilapia for 45 days. Rojtinnakorn et al. [29] showed that all turmeric extract fed fish had significant higher activities of digestive enzymes because it considered as an indicator on improvement of growth rate. Also, Xia et al. [30] showed that, curcumin supplementation has significantly improved the growth of juvenile $\mathrm{M}$. amblycephala. In addition, black pepper enhanced the absorption of curcumin, through increasing the blood concentration that extended the absorption and bioavailability of curcumin [8]. Moreover, azolla has the ability to fix the atmospheric nitrogen and removal the accumulation of mercury, arsenic, cadmium, lead, chromium, platinum and gold from waters [31]. So, it can remove the stress of pollutants that affected fish and give the chance to fish for growing normally. The current study revealed a significant increase in the activities of both GHR and IGF genes in liver tissue of Oreochromis niloticus that was exposure to azolla. These results are similar to those were recorded by other researchers [32].

There was a significant decrease in the activities of both GHR and IGF genes in the liver tissue of Oreochromis niloticus that were collected from waste water that was attributed to the increase of heavy metals in waste water that lead to decrease both of GHR and IGF. These results are in agreement with others [33] who reported decrease in both of GHR and IGF in rainbow trout (Oncorhynchus mykiss) after it was exposed to cobalt and zinc.

\section{Conclusion}

It can be concluded that addition of turmeric and black pepper powder to fish diet resulted in a significant increase in fish weight as well as an improvement in both of growth 
hormone receptor gene and insulin like growth factor gene activities in liver tissue of Nile tilapia fish (Oreochromis niloticus) that were collected from waste water. Also, Azolla has the ability to improve fish weight as well as both of growth hormone receptor gene and insulin like growth factor gene activities in liver tissue of Nile tilapia fish in waste water.

\section{Conflict of interest}

The authors declare no conflict of interest.

\section{References}

[1] El-Naggar, G.O.; Zaghloul, K. H.; Magdy, A. and Salah El-Deenand A. S. (1998): Studies on the effect of industrial water pollution along different sites of the River Nile on some physiological and biochemical parameters of the Nile tilapia, Oreochromis niloticus. $4^{\text {th }}$ Vet Med. Zag. Congress (26-28 August 1998 in Hurghada): 713-735.

[2] Zaitseva, M.; Vollenhoven, B.J. and Rogers, P.A. (2006): In vitro culture significantly alters gene expression profiles and reduces differences between myometrial and fibroid smooth muscle cells. Mol Hum Reprod, 12(3): 187 - 207.

[3] Abdel Baky, T.E.; Hagras, A.E.; Hassan, S.H. and Zyadah, M.A. (1998): Environmental impact assessment of pollution in Lake Manzala. Distribution of some heavy metals in water and sediment. J Egypt Ger Soc Zool, 26: 25-38.

[4] El-Bahr, S.M.; Korshom, M.A.; Mandour, A.A.; El-Bessomy, A.A. and Lebdah, M.A. (2007): The protective effect of Turmeric on iron overload in albino rats. Egypt J Biochem Mol Biol, 25: 94-113.

[5] Fluck, H.; Schib, R.J. and Rowson, J.M. (1976): Medicinal Plants and Their Uses. W. Foulsham and Co. Ltd, England, pp 168.

[6] Pal, S.; Choudhuri, T.; Chattopadhyay, S.; Bhattacharya, A.; Datta, G.K.; Das, T. and Sa,.G. (2001): Mechanisms of curcumin-induced apoptosis of Ehrlich's ascites carcinoma cells. Biochem Biophys ResComm, 288(3): 658-665.

[7] Majdalawieh, A. F. and Carr, R. I. (2010): In Vitro Investigation of the Potential
Immunomodulatory and Anti-Cancer Activities of Black Pepper (Piper nigrum) and Cardamom (Elettaria cardamomum). J Med Food, 13(2): 371-381.

[8] Shoba ,G. ; Joy, D. ; Joseph, T. ; Majeed, M. ; Rajendran, R. and Srinivas, P.S. ( 1988): Influence of piperine on the pharmacokinetics of curcumin in animals and human volunteers. Planta Med, 64(4):353-356.

[9] Watanabe, I. and Espinas , C.R. and Berja, N.S. and Alimagno, B.V. (1977) The utilization of the Azolla - Anabaena complex as a nitrogen fertilizer for rice. Other. International Rice Research Institute, Manila, Philippines,(76):15-16.

[10] Forni, C.; Chen, J.; Tancioni, L.; and Caiola, M.G. (2001): Evaluation of the fern Azolla for growth, nitrogen of the phosphorus removal from wastewater. Water Res, 35 (6): 1592 - 1598.

[11] Cohen-Shoel, N.; Barkay, Z.; Ilzycer, D.; Gilath, L. and Tel-Or, E. (2002): Biofiltration of toxic elements by Azolla biomass. Water Air Soil Pollut, 135(1): 93-104.

[12] Al-Jaleel, R. A. A. (2012): Use of turmeric (Curcuma longa) on the performance and some physiological traits on the broiler diets. Iraqi J VetMed, 36 (1): 51-57.

[13] Kilany, O. E. and , M.M. (2014): Turmeric and Exogenous Enzyme Supplementation Improve Growth Performance and Immune Status of Japanese quail. World's Vet J, 4(3): 20-29.

[14] Mahfouz, M.E. (2015): Ameliorative Effect of Curcumin on Aflatoxin B1_Induced Changes in Liver Gene Expression of Oreochromis niloticus. Mol Biol, 49 (2): 275-286.

[15]Abou-Elkhair, R.; Ahmed, H.A. and Selim, S. (2014): Effects of Black Pepper (Piper Nigrum), Turmeric Powder (Curcuma Longa) and Coriander Seeds (Coriandrum Sativum) and Their Combinations as Feed Additives on Growth Performance, Carcass Traits, Some Blood Parameters and Humoral Immune Response of Broiler Chickens. 
Asian- Australas J Anim Sci, 27(6):847854.

[16] Akar, A. A. (1983) : Studies on some environmental factors affecting fish farming in Egypt. Zagazig University Digital Repository ,Ph.D. thesis. Department of Agriculture University, P.26.

[17]Shved, N.; Berishvili, G.; Mazel, P.; Baroiller, J.F. and Eppler, E. (2011): Growth hormone $(\mathrm{GH})$ treatment acts on the endocrine and autocrine/paracrine $\mathrm{GH} / \mathrm{IGF}$-axis and on TNF- $\alpha$ expression in bony fish pituitary and immune organs. Fish and Shellfish Immunol., 31: 944-952.

[18] Livak, K.J. and Schmittgen, T. D. (2001): Analysis of Relative Gene Expression Data Using Real-Time Quantitative PCR and the 22DDCT Method. Methods, 25: 402-408.

[19]Eppler, E.; Berishvili, G.; Mazel, P.; Caelers, A.; Hwang, G. and Maclean, N. (2010): Insulin-like growth factor-3 (IGF-3) in male and female gonads of the tilapia: Development and regulation of gene expression by growth hormone (GH) and 17 $\alpha$-ethinylestradiol (EE2). General and Comparative Endocrinology, 167(1):128-134.

[20] Duncan, M.B. (1955): New Zealand towns as service centres. Biometrics, 11, $1-42$.

[21] Osawa, T.; Sugiyama, Y.; Inayoshi, M. and Kawakishi, S. (1995): Antioxidative activity of tetrahydrocurcuminoids. Biosci Biotechnol Biochem, 59(9): 16091612.

[22]Pransin, M. (2006): Using Turmeric (Curcuma longa) in Goldfish (Carassiu auratus) Feed. Master of Science (Aquaculture), Department of Aquaculture, Kasetsart University, p 86.

[23]Chaudhry, N.M. and Tariq, P. (2016): Bactericidal activity of black pepper, bay leaf, aniseed and coriander against oral isolates. Pak J Pharm Sci, 19(3):214-218.

[24] Basak, B.; Pramanik, A.H.; Rahmnan, M.S.; Taradar, S.U. and Roy, B.C.
(2002): Azolla (Azolla pinnata) as a feed ingredient in broiler ration. Int $\mathrm{J}$ Poult Sci, 1(1): 29-24.

[25] Canosa, L.F. ; Chang, J.P. and Peter, R.E. (2007): Neuroendocrine control of growth hormone in fish. GenComp Endocrinol, 151(1): 1-26.

[26] Duan, C. (1998): Nutritional and development of regulation of insulin like growth factor in fish. J Nutr. 128(2): 306S-314S.

[27] Kurhekar, J.V. (2013): Curcuma longa and Allium sativum as prebiotics. Bionano Front, 6(2): 327-329.

[28] Midhun, S. J. ; Arun, D. ; Edat, L. ; Sruthi, M.V.; Thushara, $\quad$ V.V.; Oommen V.; Kumar, O. S. and Divya, L. (2016): Modulation of digestive enzymes, GH, IGF-1 and IGF-2 genes in the teleost, Tilapia (Oreochromis mossambicus) by dietary curcumin. Aquacult Int, 24(5):1277-1286.

[29] Rojtinnakorn, J.; Rittiplang, S.; Tongsiri, S. and Chaibu, P. (2012): Turmeric extract inducing growth biomarker in Sand goby (Oxyeleotris marmoratus). In Proceedings of the $2^{\text {nd }}$ International Conference on Chemical, Biological and Environment Sciences (ICCEBS 2012) Bali, P:41-43

[30] Xia, S.; Ge, X.; Liu, B.; Xie, J.; Miao, L. H.; Ren, M.; Zhou, Q.; Zhang, W.; Jiang, X.; Chen, R. and Pan, L. (2015): Effects of supplemented dietary curcumin on growth and non-specific immune responses in juvenile wuchang bream (Megalobrama amblycephala). Israeli Journal - Bamidgeh, 67: 12 .

[31]Banach, A. M.; Banach, K. and Stepniewska, Z. (2012): Phytoremediation as a promising technology for water and soil purification: Azolla caroliniana Willd. As a case study. Acta Agrophysica, 19:2.

[32] Erzsebet, B. U.; Paulette, L.; Mihaiescu, T.; Mihai, B. U. and Cantor, M. (2011): The Influence of Heavy Metals on Growth and Development of Eichhornia crassipes Species, Cultivated in 
Contaminated Water. Not Bot Horti Agrobo, 39(2): 135-141.

[33] Ekinci, D.; Ceyhun, S.B.; Aksakal, E. and Erdoğan, O. (2011): IGF and GH mRNA levels are suppressed upon exposure to micromolar concentrations of cobalt and zinc in rainbow trout white muscle. Comp
Biochem Physiol C Toxicol Pharmacol, 153(3):336-341.

[34]Cho , Cowey and Watanabe ( 1985 ): Finfish nutrition in Asia : methodical approaches to research and development. International Development Research Centre (Canada), 154p.

$$
\begin{aligned}
& \text { الملخص العربي } \\
& \text { تأثير الكركم والفلقل الأسمر والأزولا علي أسماك البلطي النيلي المستزرعه علي المياه الملوثه }
\end{aligned}
$$

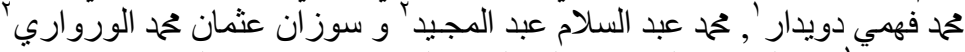

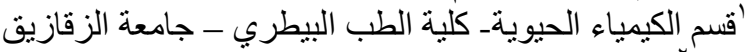

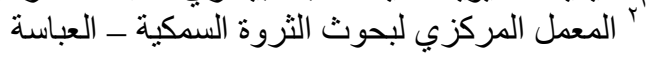

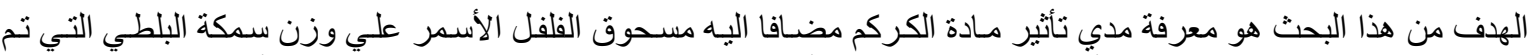

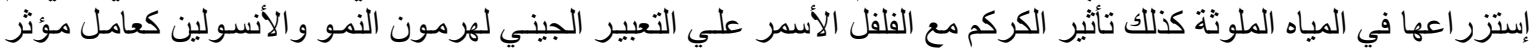

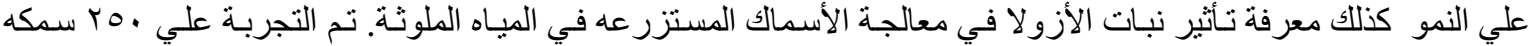

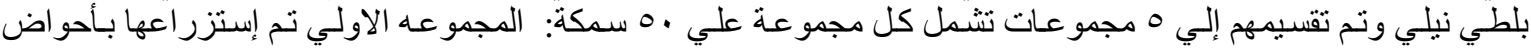

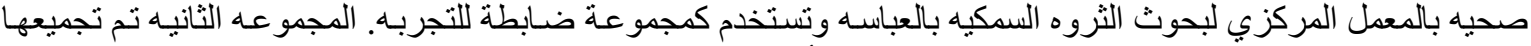

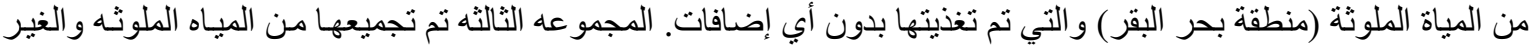

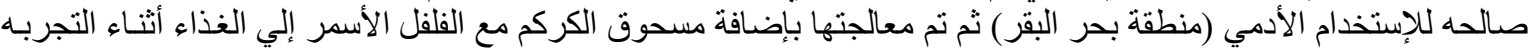

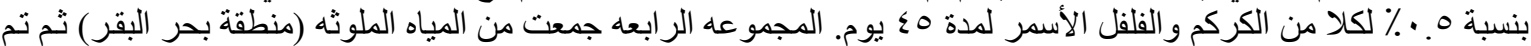

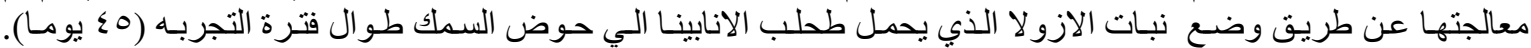

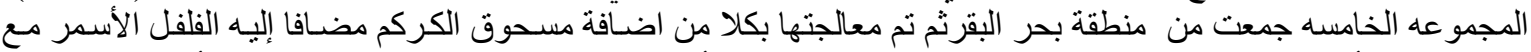

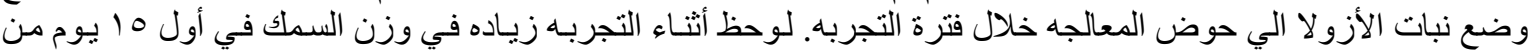

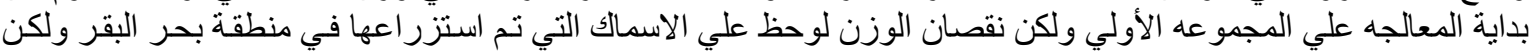

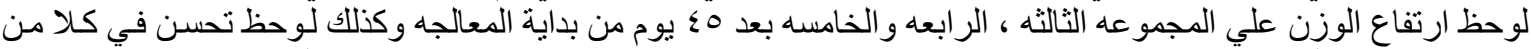

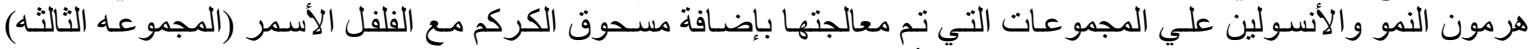

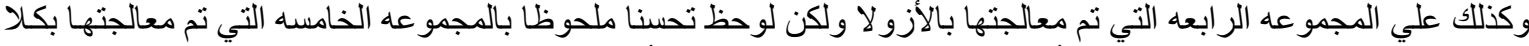

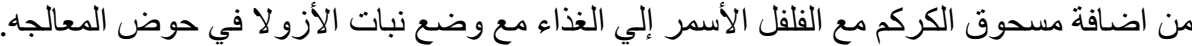

